\title{
Hemoglobin C in Newborn Sheep and Goats: A Possible Explanation for its Function and Biosynthesis
}

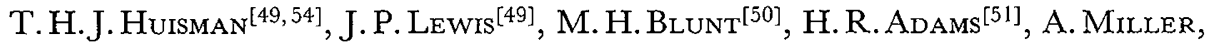 \\ Andrée M. Dozy and Evalyn M. Boyd
}

Veterans Administration Hospital and Division of Protein Chemistry, Medical College of Georgia, Augusta, Georgia, USA

Extract

Chromatographic analyses of the hemoglobins of newborn kids over a postnatal period of 120 to 140 days have shown that fetal hemoglobin is replaced by $\beta^{\mathrm{C}}$ chain-containing hemoglobin types rather than by normal $\beta^{\mathrm{A}}$ chain-containing adult hemoglobin components. These $\beta^{\mathrm{C}}$ chain-containing hemoglobins are the same as those observed in adult goats subjected to severe blood-loss anemia. A similar, but quantitatively different, phenomenon was also observed in newborn lambs. The increase in $\beta^{\mathrm{C}}$ chain production is preceded by an elevation of an erythropoietic stimulating factor (ESF) in blood plasma. When ESF extract of human urinary origin was injected into either young lambs or a young kid, an increased production of $\beta^{\mathrm{C}}$ chain-containing hemoglobins was observed.

\section{Speculation}

It is postulated that the production of $\beta^{\mathrm{C}}$ chain-containing hemoglobin types in the newborn kid is a physiological adjustment that allows these fast growing animals to supply oxygen to the tissues in an easy fashion. The effects observed as a response to an increased ESF activity in serum are interpreted to be the result of two separate mechanisms that differ qualitatively and quantitatively. The low sensitivity of sheep to the stimulus of an elevated ESF activity is explained by a possible formation of an activator-inhibitor complex resulting in a decreased activation of the silent $\mathrm{Hb}_{\beta} \mathrm{c}$ structural gene.

\section{Introduction}

Considerable heterogeneity can be observed in the hemoglobin of the adult sheep and goat. The various forms include three adult hemoglobins (Hbs A, B and D) found in different combinations in individual animals of both species. A specific fetal hemoglobin (Hb-F) is also present in newborn lambs and kids. The synthesis of these hemoglobin types involves specific $\beta, \gamma$ and $\alpha$ structural genes (table IA). The heterogeneity of the goat hemoglobin is particularly marked because of the existence of two nonallelic $\alpha$ structural genes, the $\mathrm{Hb}_{\mathrm{I} \alpha}$ and $\mathrm{Hb}_{\mathrm{II}_{\alpha}}$ genes, which possibly arose through duplication.
A dormant gene, the $\mathrm{Hb}_{\beta} \mathrm{C}$ gene, exists in these ruminants and becomes activated in certain animals when subjected to severe anemia. The product of this gene differs considerably from the $\beta^{\mathrm{A}}$ chains observed in the adult sheep and goat; the $\beta^{\mathrm{C}}$ chain contains only 141 amino acid residues, whereas 145 residues are present in the $\beta^{\mathrm{A}}$ chains; it contains one isoleucyl residue and no methionine and differs from the $\beta^{A}$ chain in several positions. Only a small percentage of $\mathrm{Hb}-\mathrm{C}$ is observed in lambs up to 2 months of age [10, 11, 46], if the lamb is also carrying the $\mathrm{Hb}_{\beta} \mathrm{A}$ gene. Minute amounts of $\mathrm{Hb}-\mathrm{C}$ are observed in adult A sheep, while the $\beta^{\mathrm{C}}$ production in nonanemic adult goats varies be- 
tween 5 and $10 \%[24,26]$. A partial activation of this $\mathrm{Hb}_{\beta} \mathrm{C}$ gene will complicate the hemoglobin heterogeneity of these animals; a moderately anemic goat with a heterozygosity for the $\mathrm{Hb}_{\beta} \mathrm{D}$ allele will produce six distinct hemoglobin types (table IB). Oxygen dissociation curves of blood samples in vitro obtained from normal and anemic goats have shown that $\mathrm{Hb}-\mathrm{C}$ chaincontaining red blood cells of the anemic goat exhibit a decreased affinity for molecular oxygen with a concurrent increase in the Bohr effect [28].

This study examines the production of the $\beta \mathrm{C}$ chain in newborn lambs and kids. Evidence will be presented to indicate that, shortly after birth, the fetal hemoglobin in the newborn goat is replaced almost entirely by the $\beta \mathrm{C}$ chain and not by the $\beta$ chains that normally occur in adult hemoglobin types. A similar phenom- enon is observed to a lesser extent in newborn lambs. The results of investigations made in an attempt to explain the notable increase in the biosynthesis of the $\beta^{\mathrm{C}}$ chain shortly after birth will also be presented, and physiological implications will be considered.

\section{Animals}

\section{Materials and Methods}

Three newborn lambs of the Rambouillet breed (Nos.6192, 6193, and 6176), the progeny of AA ewes and an AA ram, were studied [53].

Twelve newborn kids of domestic stock were available. Five were homozygous for $\mathrm{Hb}-\mathrm{A}$ (AA), three were heterozygous for the $\mathrm{Hb}_{\beta} \mathrm{D}$ allele $(\mathrm{AD})$, three were heterozygous for the $\mathrm{Hb}_{I_{\alpha}} \mathrm{B}$ allele $(\mathrm{AB})$ and one was

Table IA. Structural genes involved in the synthesis of hemoglobins in sheep and goats

\begin{tabular}{|c|c|c|c|}
\hline Species & Gene & Remarks & References \\
\hline \multirow[t]{4}{*}{ Sheep } & $\mathrm{Hb}_{\beta} \mathrm{A} ; \mathrm{Hb}_{\beta} \mathrm{B}$ & $\begin{array}{l}\text { The } \beta^{\mathrm{A}} \text { chain is found in } \mathrm{Hb}-\mathrm{A} \text {, and the } \beta^{\mathrm{B}} \text { chain in } \mathrm{Hb}-\mathrm{B} \text {. } \\
\text { Individual animals are either heterozygous or homozygous. } \\
\text { The two chains differ in positions } 50,58,75,76,120,129,144 \text {. }\end{array}$ & $\begin{array}{l}{[3,7,8,20,} \\
46]\end{array}$ \\
\hline & $\mathrm{Hb}_{\beta} \mathrm{c}$ & $\begin{array}{l}\text { A 'dormant' gene. The } \beta^{\mathrm{C}} \text { chain is either absent or present in small } \\
\text { amounts in adult sheep carrying the } \mathrm{Hb}_{\beta \mathrm{A}} \text { gene. It replaces the } \\
\beta^{\mathrm{A}} \text { chain, but not the } \beta^{\mathrm{B}} \text { chain, in severely anemic sheep. The } \beta^{\mathrm{C}} \\
\text { chain contains } 141 \text { amino acid residues and differs from the } \beta^{\mathrm{A}} \text { in at } \\
\text { least } 16 \text { positions. }\end{array}$ & $\begin{array}{l}{[3,6,7,8} \\
10,37,43 \\
46]\end{array}$ \\
\hline & $\mathrm{Hb}_{\gamma}$ & $\begin{array}{l}\text { The } \gamma \text { chain is present in fetal hemoglobin. Hb-F is not observed } \\
\text { in adult sheep. }\end{array}$ & {$[46]$} \\
\hline & $\mathrm{Hb}_{\alpha} \mathrm{A} ; \mathrm{Hb}_{\alpha} \mathrm{D}$ & $\begin{array}{l}\text { The } \alpha \text { chains are observed in adult and fetal Hb types. The } \mathrm{Hb}_{\alpha \mathrm{D}} \\
\text { gene is a rare allele; the } \alpha^{\mathrm{D}} \text { chain differs from } \alpha^{\mathrm{A}} \text { in position } 15 \\
(\text { GIy } \rightarrow \text { Asp). }\end{array}$ & {$[27,44,47]$} \\
\hline \multirow[t]{5}{*}{ Goat } & $\mathrm{Hb}_{\beta} \mathrm{A} ; \mathrm{Hb}_{\beta} \mathrm{D}$ & $\begin{array}{l}\text { The } \beta^{\mathrm{A}} \text { chain is found in } \mathrm{Hb}-\mathrm{A} \text {. The } \mathrm{Hb}_{\beta \mathrm{D}} \text { gene is an allele. } \\
\text { The } \beta^{\mathrm{D}} \text { chain differs from the } \beta^{\mathrm{A}} \text { chain in position } 21 \text { (Asp } \rightarrow \mathrm{His} \text { ). }\end{array}$ & {$[1]$} \\
\hline & $\mathrm{Hb}_{\beta} \mathrm{C}$ & $\begin{array}{l}\text { A 'dormant' gene. The } \beta^{\mathrm{C}} \text { chain is present from } 3 \text { to } 10 \% \text { in non- } \\
\text { anemic adult goats. It replaces the } \beta^{\mathrm{A}} \text { and } \beta^{\mathrm{D}} \text { chains in severely } \\
\text { anemic goats. The goat } \beta^{\mathrm{C}} \text { chain differs from the sheep } \beta^{\mathrm{C}} \text { chain } \\
\text { in possibly one position ( } 50 \mathrm{Thr} \rightarrow \text { Ser). }\end{array}$ & {$[1,24]$} \\
\hline & $\mathrm{Hb}_{\gamma}$ & $\begin{array}{l}\text { The } \gamma \text { chain is present in fetal hemoglobin; Hb-F is not observed } \\
\text { in adult goats. }\end{array}$ & {$[22]$} \\
\hline & $\mathrm{Hb}_{\mathrm{I} \alpha} ; \mathrm{Hb}_{\mathrm{I}_{\alpha} \mathrm{B}}$ & 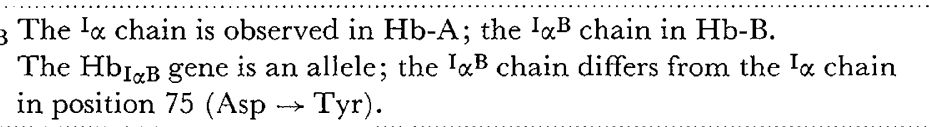 & {$[24,26]$} \\
\hline & $\mathrm{Hb}_{\mathrm{II}_{\alpha}}{ }^{*}$ & $\begin{array}{l}\text { A nonaellic gene likely arisen from the } \mathrm{Hb}_{\mathrm{I}_{\alpha}} \text { gene by duplication. } \\
\text { The } \mathrm{I}_{\alpha} \text { and } \mathrm{II}_{\alpha} \text { chains differ in positions } 19,26,113,115 \text {. The } \mathrm{II}_{\alpha} \\
\text { chains combine with } \beta^{\mathrm{A}}, \beta^{\mathrm{C}} \text { and } \beta^{\mathrm{D}} \text { chains to form } \mathrm{Hb} \text { types which } \\
\text { cannol be separateci from ine }{ }^{\alpha} \text { containing } \mathrm{H} H \mathrm{ib} \text { iypes by sianciarci } \\
\text { clectrophoretic procedures. No allele is yet observed. }\end{array}$ & {$[18,25,26]$} \\
\hline
\end{tabular}

* 'The !l $\alpha$ chain is also designaled as $\alpha^{\prime}$ and $\alpha^{\alpha^{\prime}}$ | $25 ; 36$ ]. 
homozygous for the $\mathrm{Hb}_{\mathrm{I}_{\alpha} \mathrm{B}}$ allele (BB). Blood samples of these animals were collected within 24 hours after birth, and various hematological values and the quantities of the hemoglobin components were determined. Similar studies were made on five of these newborns at weekly to biweekly intervals for more than 4 months; these five animals were Nos. 122 (AA), 119 (AD), 158 (AD), $100(\mathrm{AB})$ and $125(\mathrm{BB}) . \mathrm{A} 15 \mathrm{ml}$ blood sample was collected from each of the remaining seven newborns on four occasions over a period of 100 days to determine the erythropoietic stimulating activity of the serum; the time between two collections from one newborn kid varied between 20 and 30 days. One larger kid (goat 105, AB) was used to study the in vivo effect of an isolated erythropoietic stimulating factor (ESF) on the formation of specific hemoglobin components.

\section{Hematological Studies}

These analyses included the determinations of the total hemoglobin ( $\mathrm{Hb} \mathrm{g} \%$ ), packed cell volume (PGV\%), red cell $\left(\mathrm{RBC} 10^{6} / \mathrm{mm}^{3}\right.$ ) and reticulocyte counts following standard laboratory procedures [48]. The method used for determining the ESF activity of serum was a modification of the technique described by Pavlovic-Kentera et al. [38]. This modification, which uses an oxygen-nitrogen mixture with $8 \% \mathrm{O}_{2}$ to produce polycythemia in assay mice, has been described elsewhere [33].

Table IB. Major hemoglobin types observed in sheep and goats

\begin{tabular}{|c|c|c|c|}
\hline Species & Nonanemic animal & Severely anemic animal & $\mathrm{Hb}-\mathrm{F}$ in newborn \\
\hline Sheep AA & $\mathrm{A}: \alpha_{2} \mathrm{~A} \beta_{2} \mathrm{~A}$ & $\mathrm{C}: \alpha_{2} \mathrm{~A} \beta_{2} \mathrm{C}$ & $\alpha_{2} \mathrm{~A}_{2}$ \\
\hline Sheep BB & $\mathrm{B}: \alpha_{2} \mathrm{~A} \beta_{2}^{\mathrm{B}}$ & $\mathrm{B}: \alpha_{2} \mathrm{~A} \beta_{2} \mathrm{~B}$ & $\alpha_{2} \mathrm{~A}_{2}$ \\
\hline Sheep AB & $A+B$ & $\mathrm{C}+\mathrm{B}$ & $\alpha_{2} \mathrm{~A}_{2}$ \\
\hline Sheep AD & $\mathrm{A}: \alpha_{2}{ }^{\mathrm{A}} \beta_{2} \mathrm{~A}$ & $\mathrm{C}: \alpha_{2}{ }^{\mathrm{A}} \beta_{2} \mathrm{C}$ & $\alpha_{2} \mathrm{~A}_{2}$ \\
\hline & $\mathrm{D}: \alpha_{2}{ }^{\mathrm{D}} \beta_{2} \mathrm{~A}$ & $\alpha_{2} \mathrm{D} \beta_{2} \mathrm{C}$ & $\alpha_{2} D_{\gamma_{2}}$ \\
\hline Goat AA* & $\mathrm{A}:{ }^{\mathrm{I}} \alpha_{2} \beta_{2}{ }^{\mathrm{A}}+{ }^{\mathrm{II}} \alpha_{2} \beta_{2} \mathrm{~A}$ & $\mathrm{C}:{ }^{\mathrm{I}} \alpha_{2} \beta_{2} \mathrm{C}+\mathrm{II}_{\alpha_{2} \beta_{2} \mathrm{C}}$ & $\mathrm{I}_{\alpha_{2}} \gamma_{2}+\mathrm{II}_{\alpha_{2} \gamma_{2}}$ \\
\hline Goat $\mathrm{AD}^{*}$ & $\begin{array}{l}\mathrm{A}:{ }^{\mathrm{I}} \alpha_{2} \beta_{2} \mathrm{~A}+\mathrm{II}_{\alpha_{2} \beta_{2} \mathrm{~A}} \\
\mathrm{D}:{ }^{\mathrm{I}} \alpha_{2} \beta_{2} \mathrm{D}+\mathrm{II}_{\alpha_{2} \beta_{2} \mathrm{D}}\end{array}$ & $\mathrm{C}: \mathrm{I}_{\alpha_{2}} \beta_{2} \mathrm{C}_{+} \mathrm{II}_{\alpha_{2} \beta_{2}} \mathrm{C}$ & $\mathrm{I}_{\alpha_{2} \gamma_{2}}+\mathrm{II}_{\alpha_{2} \gamma_{2}}$ \\
\hline Goat BB & $\mathrm{A}: \quad \mathrm{II}_{\alpha_{2} \beta_{2} \mathrm{~A}}$ & $\mathrm{C}: \quad \mathrm{II}_{\alpha_{2} \beta_{2} \mathrm{C}}$ & $\mathrm{II}_{\alpha_{2} \gamma_{2}}$ \\
\hline Goat $\mathrm{AB}^{*}$ & $\begin{array}{l}\mathrm{B}:{ }^{\mathrm{I}} \alpha_{2}{ }^{\mathrm{B}} \beta_{2} \mathrm{~A} \\
\mathrm{~A}:{ }^{\mathrm{I}} \alpha_{2} \beta_{2} \mathrm{~A}+{ }^{\mathrm{II}} \alpha_{2} \beta_{2} \mathrm{~A} \\
\mathrm{~B}:{ }^{\mathrm{I}} \alpha_{2}{ }^{\mathrm{B}} \beta_{2}{ }^{\mathrm{A}}\end{array}$ & $\mathrm{C}:{ }^{\mathrm{I}_{\alpha_{2}}{ }^{\mathrm{B}} \beta_{2}{ }_{2} \mathrm{C}}+{ }^{\mathrm{II}} \alpha_{2} \beta_{2} \mathrm{C}$ & $\begin{array}{l}\mathrm{I}_{\alpha_{2}} \mathrm{~B} \gamma_{2} \\
\mathrm{I}_{\alpha_{2} \gamma_{2}}+\mathrm{II}_{\alpha_{2} \gamma_{2}} \\
\mathrm{I}_{\alpha_{2}} \mathrm{~B}_{\gamma_{2}}\end{array}$ \\
\hline
\end{tabular}

* In order to facilitate the presentation of the experimental data the mixtures of the $\mathrm{I}_{\alpha_{2}} \beta_{2} \mathrm{~A}_{+} \mathrm{II}_{\alpha_{2}} \beta_{2}{ }^{\mathrm{A}}$ components,

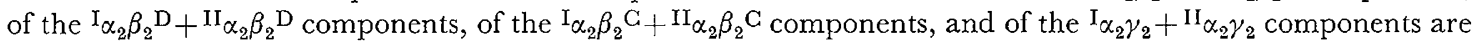
indicated in this paper simply as $\alpha_{2} \beta_{2}{ }^{\mathrm{A}}(\mathrm{Hb}-\mathrm{A}), \alpha_{2} \beta_{2} \mathrm{D}$ (Hb-D), $\alpha_{2} \beta_{2} \mathrm{C}$ (Hb-C), and $\alpha_{2} \gamma_{2}$ (Hb-F/A), respectively.

Fig. 1. The separation of the hemoglobin components of newborn goat 100 , heterozygous for the $\mathrm{Hb}_{\mathrm{I} \alpha} \mathrm{B}$ allele, by DEAE-Sephadex chromatography. For explanation see text.

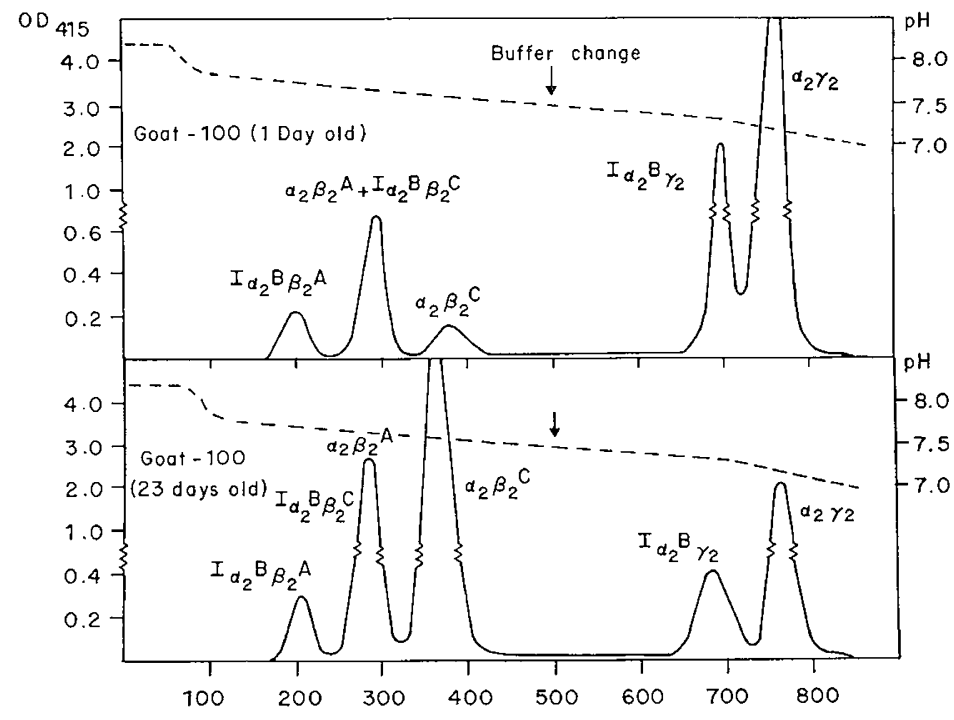

MI Effluent 


\section{Hemoglobin Analysis}

The methods used for preparing red cell hemolysates and for starch gel electrophoresis have been described [21]. Sheep and goat hemoglobins were quantitated by chromatographic analyses on columns of DEAESephadex A-50 [14, 23]. It was not possible to separate $\mathrm{Hb}-\mathrm{F}$ (ovine) from the adult $\mathrm{Hb}-\mathrm{A}$ (ovine) with this procedure. The quantities of sheep $\mathrm{Hb}-\mathrm{F}$ were determined by CM-cellulose chromatography using columns of $22 \times 0.9 \mathrm{~cm}$ and an $0.01 \mathrm{M}$ sodium phosphate buffer, $\mathrm{pH}$ 6.8, as the initial developer. $\mathrm{Hb}-\mathrm{F}$ is eluted as the first component in this system; the remaining hemoglobin fractions were recovered as a mixture by introducing the same phosphate buffer, but with a $\mathrm{pH}$ of 8.4. All four possible hemoglobins of newborn lambs can be quantitated by the application of these two chromatographic techniques.

Various hemoglobin components to be observed in the newborn kids, namely, Hb-D $\left(\alpha_{2} \beta_{2} \mathrm{D}\right)$, Hb-B $\left({ }^{\mathrm{I}} \alpha_{2}{ }^{\mathrm{B}} \beta_{2} \mathrm{~A}\right)$, Hb-A $\left(\alpha_{2} \beta_{2} \mathrm{~A}\right), \quad \mathrm{Hb}-\mathrm{C} \quad\left(\alpha_{2} \beta_{2} \mathrm{C}\right), \quad \mathrm{Hb}-\mathrm{F} / \mathrm{B}$ $\left({ }^{I_{2}}{ }^{B} \gamma_{2}\right)$, and Hb-F/A $\left(\alpha_{2} \gamma_{2}\right)$ can be separated by DEAE-Sephadex chromatography. Chromatograms of the hemoglobin from a young kid one day and 23 days after birth are shown in figure 1. Separation of the two fetal hemoglobins of this young $A B$ kid required the application of a buffer, $\mathrm{pH} 6.5$, for complete recovery. Hemoglobin components of the $\mathrm{I}_{\alpha}$ series and of the II $\alpha$ series could not be separated by this procedure (tables IA and IB); these components are therefore quantitated as one fraction and are identified simply as $\alpha_{2} \chi_{2}$ components ( $\chi$ being either $\beta^{\mathrm{A}}, \beta^{\mathrm{D}}, \beta^{\mathrm{C}}$, or $\gamma$ chains). A second complicating factor was the chromatographic behavior of the $\mathrm{I}_{\alpha_{2}}{ }^{\mathrm{B}} \beta_{2} \mathrm{C}$ component. This hemoglobin has a chromatographic mobility in our system about the same as that of $\mathrm{Hb}-\mathrm{A}$ or $\alpha_{2} \beta_{2} \mathrm{~A}$. A mixture of various quantities of the ${ }^{\mathrm{I}} \alpha_{2}{ }^{\mathrm{B}} \beta_{2} \mathrm{C}$ and $\alpha_{2} \beta_{2} \mathrm{~A}$ components is present in the second zones of chromatograms of hemolysates obtained from goats with a heterozygosity or a homozygosity for the $\mathrm{Hb}_{\mathrm{I}_{\alpha} \mathrm{B}}$ allele. This unfortunate complication made it necessary to estimate the amounts of the two components in these zones from the amount of $\mathrm{Hb}-\mathrm{B}\left({ }_{\alpha_{2}}{ }^{\mathrm{B}} \beta_{2} \mathrm{~A}\right)$ observed in zone $\mathrm{I}$, assuming a ratio for $\mathrm{Hb}-\mathrm{B}$ and $\mathrm{Hb}-\mathrm{A}$ of $1: 3$ in the heterozygous $A B$ goat [25] and of $3: 2$ in the homozygous $\mathrm{BB}$ goat [18]. The values for the relative amounts of the $\beta^{\mathrm{A}}$ chain-containing hemoglobins in these goats were therefore derived from the sum of the percentages of zone $\mathrm{I}(\mathrm{Hb}-\mathrm{B})$, multiplied by the appropriate factor. Those of the $\beta^{\mathrm{C}}$ chain-containing hemoglobins were calculated from the sum of zone III $\left(\alpha_{2} \beta_{2} \mathrm{C}\right)$ and zone II, minus the calculated amounts of the $\alpha_{2} \beta_{2}{ }^{A}$ component; those of the $\gamma$ chain-containing hemoglobins, from the sum of the percentages of zones IV and V. No such complicating factors were encountered in the $A A$ and $A D$ newborn kids; the $H b-D$ $\left(\alpha_{2} \beta_{2} \mathrm{D}\right)$ was observed in a zone well separated from the $\mathrm{Hb}-\mathrm{A}[1]$.

\section{Isolation of Erythropoietic Stimulating Factor (ESF)}

The ESF factor injected into two lambs (see section Results) was isolated from the urine of a patient with paroxysmal nocturnal hemoglobinuria; the ESF factor injected into goat 105 (see section Results) was isolated from the urine of a preterminal patient with an anemia secondary to multiple myeloma. The ESF fractions were prepared and standardized in terms of standard $B$ units [52] according to LEwIs et al. [32]. The ESF fraction (1.9 ESF U/mg) injected into the lambs was also treated with tannic acid [19] and was dissolved in serum obtained from an anemic sheep. The ESF fraction (24.3 ESF U/mg) injected into goat 105 was dissolved in normal goat serum.

\section{Results}

\section{The $\beta \mathrm{C}$ Production in Newborn Lambs}

Figure 2 summarizes the data obtained for 3 lambs homozygous for the $\mathrm{Hb}_{\beta} \mathrm{A}$ gene studied for a period of 140 days after birth. The animals showed initial decreases in the $\mathrm{Hb}$ and PGV levels observed by others $[2,40]$. The lowest levels were recorded about 20 days after birth, while values comparable to those observed at birth were found 20 days later. The red blood cell counts were variable during the first three weeks after birth, while the values after 2 months were higher than those observed at birth and more comparable to values found in adult sheep. Reticulocytes were virtually absent at birth; a slight increase (to maximally $2 \%$ ) was seen during the first 25 days after birth. There was a decrease in the mean cell volume (MCV) after birth, followed by a slight macrocytosis; adult values were observed from the 40 th day. The birth weights of the animals were $3.9,3.9$, and $3.8 \mathrm{~kg}$; 30 days after birth, they weighed $9.8,10.0$, and $12.3 \mathrm{~kg}$, and after 60 days, $14.6,14.6$, and $16.8 \mathrm{~kg}$, respectively. The Hb-F levels at birth were 95.3, 98.5, and $98.3 \%$ and decreased after birth; none was detectable after 40 days, which is in agreement with the observations by others $[12,15]$. Hb-G $\left(\alpha_{2} \beta_{2} \mathrm{C}\right)$ was virtually absent at birth, but increased steadily during the following 2 weeks. The highest amounts, between 5 and $6 \%$, were recorded from the 14 th to the 20 th day, which would indicate that about $10 \%$ of the adult hemoglobin, replacing $\mathrm{Hb}-\mathrm{F}$, was $\mathrm{Hb}-\mathrm{G}$ (the actual percentages for the 3 lambs on day 14 were $13.2,12.5$, and $7.6 \%$; and on day $20,8.3,8.0$, and $5.0 \%$, respectively). The amount of $\mathrm{Hb}-\mathrm{C}$ decreased rather slowly after this period; values of about $1.2 \%$ were recorded after 76 days. 
The Effect of ESF-Rich Urinary Extract on the $\mathrm{Hb}-\mathrm{C}$ Production in Lambs

The twin lambs (Nos.6192 and 6193) were injected intraperitoneally with $190 \mathrm{ESF} \mathrm{U} / \mathrm{kg} 76$ days after birth, while lamb No.6176, a control, received a saline injection on the same day. Food was withheld from these animals one day prior to the injection, the day of injection and one day after the injection. The $\mathrm{Hb}-\mathrm{C}$ levels increased to about 3 to $5 \%$ within approximately 14 days after the injection; these levels were maintained for about two weeks, after which time a gradual decrease was observed in both animals (fig. 2). The percentage of $\mathrm{Hb}-\mathrm{C}$ in the control continued to decrease to levels of about 0.2 to $0.4 \%$. No significant changes in the hematological parameters were observed, nor was $\mathrm{Hb}-\mathrm{F}$ detectable at any time during these experiments.

\section{The $\beta^{\mathrm{C}}$ Production in Newborn Goats}

The fetal hemoglobin in 12 newborn kids varied from 86.0 to $98.1 \%$. Similar studies as described for

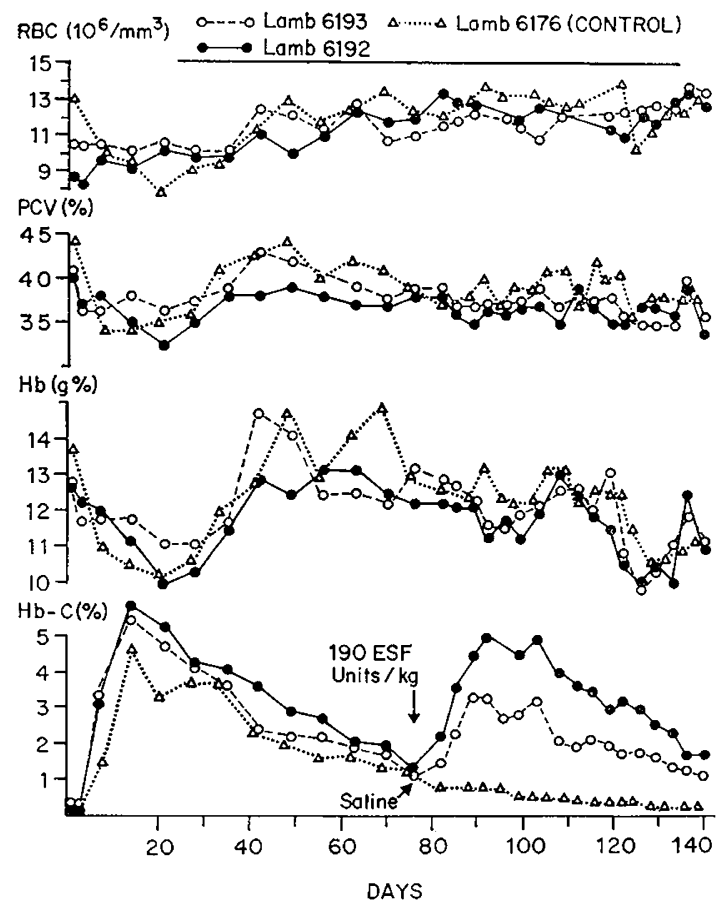

Fig. 2. The changes in total $\mathrm{Hb}(\mathrm{g} \%), \mathrm{PCV}(\%)$, total $\mathrm{RBC}\left(10^{6} / \mathrm{mm}^{3}\right)$ values and in the percentages of the $\mathrm{Hb}-\mathrm{C}$ in twin lambs (Nos.6192 and 6193) and in lamb No.6176, all homozygous for the $\mathrm{Hb}_{\beta} \mathrm{A}$ gene, from birth to 140 days. Lambs Nos. 6192 and 6193 were each injected with 190 U ESF per $\mathrm{kg}$ body weight intraperitoneally on day 76 ; saline was injected on the same day in lamb No. 6176. the three lambs were made in 5 goats, one homozygous for the $\mathrm{Hb}_{\beta} \mathrm{A}$ gene, two heterozygous for the $\mathrm{Hb}_{\beta} \mathrm{D}$ allele, one heterozygous for the $\mathrm{Hb}_{\alpha_{\alpha}} \mathrm{B}$ allele, and one homozygous for this allele. The results obtained for two of these animals are presented in figure 3 . The changes in the hematological data were comparable with those recorded for the newborn lambs, except for a much larger increase in the red blood cell counts. The initial red cell count of $9.3 .10^{6} / \mathrm{mm}^{3}$ in goat No. 119 decreased slightly during the first 10 days after birth, but rose rapidly to the normal adult value of 20 to $23.10^{6} / \mathrm{mm}^{3}$. The mean corpuscular volume decreased from an initial $34.5 \mu^{3}$ to about $17 \mu^{3}$. These observations correspond with those made by BARTELs et al. $[2,40]$. The reticulocyte counts increased from initial values of $0-0.2 \%$ to approximately $2 \%$ on day 20 , followed by a gradual decrease. Similar changes were also seen in the newborn BB kid (fig. 3 B); the total hemoglobin and PCV values, but not the RBC counts, were usually somewhat lower in this animal than those found in the other four newborns. The mean values for the total $\mathrm{Hb}, \mathrm{PCV}$, and $\mathrm{RBC}$ determined between days 60 and 126 for goat No. 119 were $11.6 \mathrm{~g} \%$, $35.5 \%$, and $21.5 .10^{6} / \mathrm{mm}^{3}$ and for goat $12511.1 \mathrm{~g} \%$, $33 \%$, and $22.6 .10^{6} / \mathrm{mm}^{3}$, respectively. The one fetal hemoglobin component in the $\mathrm{AA}$ and $\mathrm{AD}$ goats and the two fetal components in the $\mathrm{AB}$ and $\mathrm{BB}$ goats disappeared rapidly; no $\mathrm{Hb}-\mathrm{F}$ was demonstrable 40 days after birth. The $\beta^{\mathrm{C}}$ containing hemoglobins, which were almost absent at birth, rapidly increased; a maximum of over $80 \%$ (even $99 \%$ in goat 119) was observed around 40 to 50 days after birth. The $\beta^{\mathrm{A}}$ chain-containing hemoglobin components initially showed (on days 4 to 10 after birth) a slight rise followed by a decrease to very low values. After 60 days, the $\beta^{\mathrm{C}}$ containing hemoglobins were gradually replaced by the $\beta^{A}$ containing hemoglobins. The growth rates of newborn kids were comparable to those observed for the three lambs.

\section{The ESF Activity Observed in the Serum of Newborn Kids}

The activity of ESF was determined in the sera of 7 additional newborn kids rather than in the 5 newborns under study. The reason for this complication was the large volume of blood $(15 \mathrm{ml})$ needed; the resulting mild anemia could probably cause an undesirable increase in $\beta \mathrm{C}$ production. Four blood samples were obtained from each of these 7 animals; the samples were collected with time intervals of 20-30 days. The results of these determinations are presented in figure 4 as the percentages of injected $\mathrm{Fe}^{59}$ incorporated during 48 hours by the RBC of polycythemic assay mice due to $1 \mathrm{ml}$ of goat serum. The data are compared with the changes in the hematological parameters observed for all five goats under study and with the chan- 


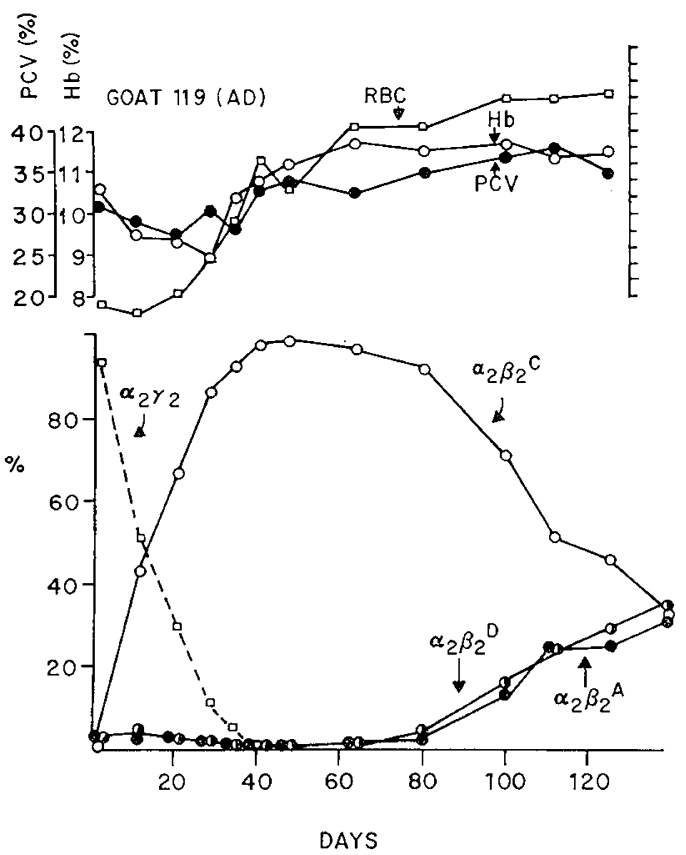

ges in the percentages of the $\gamma, \beta^{\mathrm{A}}, \beta^{\mathrm{D}}$ and $\beta^{\mathrm{C}}$ chain-containing hemoglobin types, as they were calculated from the various chromatograms. Although the values for the $\mathrm{Fe}^{59}$ incorporation showed a relatively large deviation, a maximum could be observed 15 to 20 days after birth. This maximum was about $50 \%$ higher than the values found on days 4 to 7 after birth and about twice those found in goats 60 to 100 days of age. The increase in ESF activity corresponded rather well with the increase in total $\mathrm{Hb}, \mathrm{PCV}$ values and $\mathrm{RBC}$ counts, and with the rapid production of the $\beta \mathrm{C}$ polypeptide chain. The maximum $\beta \mathrm{C}$ production was reached 20 to 25 days after the maximal ESF activity was observed.

\section{The Effect of ESF-Rich Urinary Extract on the $\beta \mathrm{C}$ Production in the Goat}

Goat number 105, having a heterozygosity for the $\mathrm{Hb}_{\mathrm{I}_{\alpha} \mathrm{B}}$ allele was used. The animal was about 6 months old and weighed $18 \mathrm{~kg}$ at the start of the experiment; the level of $\beta \mathrm{C}$ chain-containing hemoglobins was 3 to $5 \%$. A large amount of erythropoietic stimulating material (602 ESF U/kg) was injected intraperitoneally; food was withheld one day before injection, the day of injection, and one day after injection. Hematological and hemoglobin data were collected at varied intervals for 70 days. The animal responded with a marked polycythemia. The maximum was reached 13 days after the injection, when the total hemoglobin level had increased from 13 to $14.4 \mathrm{~g} \%$, the PCV values from 35 to $42 \%$, and the RBC counts from about 25 to $33.10^{6} / \mathrm{mm}^{3}$. Normal values were found about 30 to 40 days later. The level of the $\beta^{\mathrm{C}}$ chain-containing
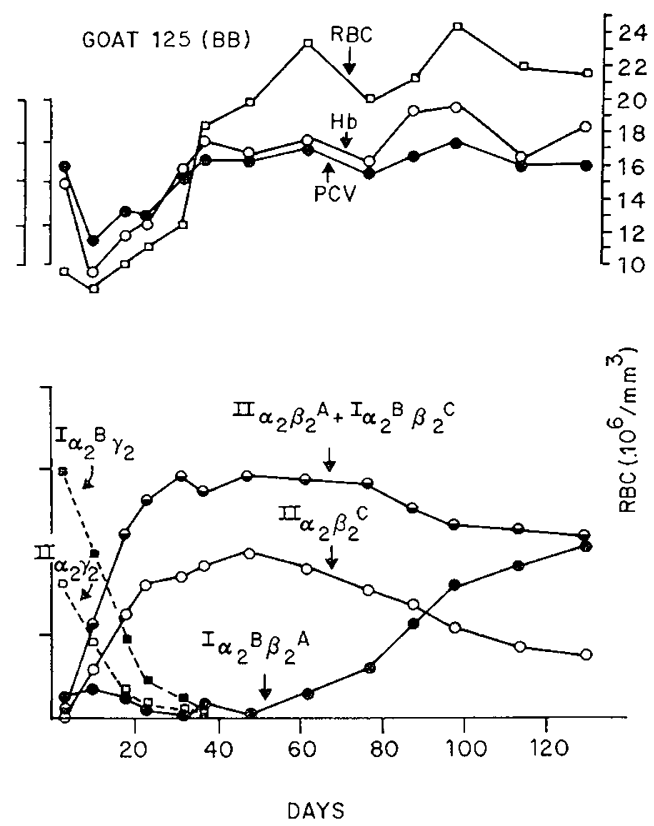

Fig. 3. The changes in total $\mathrm{Hb}(\mathrm{g} \%), \operatorname{PCV}(\%)$, total $\mathrm{RBC}\left(10^{6} / \mathrm{mm}^{3}\right)$ values and in percentages of $\gamma, \beta^{\mathrm{A}}$ (and $\beta^{\mathrm{D}}$ ), and $\beta^{\mathrm{C}}$ containing hemoglobin components in newborn goats from birth to 140 days.

$A$. Data observed for goat 119, heterozygous for the $\mathrm{Hb}_{\beta \mathrm{D}}$ allele. The increases in the percentages of $\mathrm{Hb}-\mathrm{D}$ $\left(\alpha_{2} \beta_{2}{ }^{D}\right)$ and Hb-A $\left(\alpha_{2} \beta_{2}{ }^{\mathrm{A}}\right)$ after day 60 are about the same; both hemoglobin types replace Hb-C $\left(\alpha_{2} \beta_{2} \mathrm{C}\right)$ at the same rate.

$B$. Data observed for goat 125 , homozygous for the $\mathrm{Hb}_{\mathrm{I}_{\alpha \mathrm{B}}}$ allele. The two fetal hemoglobins ( $\mathrm{II}_{\alpha_{2} \gamma_{2}}$ and $\left.\mathrm{r}_{\alpha_{2}}{ }^{\mathrm{B}} \gamma_{2}\right)$ disappear after birth at approximately the same rate. The two $\beta^{\mathrm{C}}$ containing hemoglobins increased

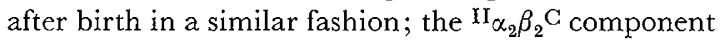
was pure, while the second was a mixture of the $\mathrm{II}_{\alpha_{2}} \beta_{2} \mathrm{~A}$ and $\mathrm{I}_{\alpha_{2}}{ }^{\mathrm{B}} \beta_{2}{ }_{2}$ components. On day 48 the level of $\mathrm{Hb}-\mathrm{B}$ $\left({ }^{\mathrm{I}} \alpha_{2} \mathrm{~B} \beta_{2} \mathrm{~A}\right)$ was $1.1 \%$ and the calculated amount of $\mathrm{Hb}-\mathrm{A}\left({ }^{1} \alpha_{2} \beta_{2}{ }^{\mathrm{A}}\right) 0.7 \%$, indicating that the largest $\mathrm{Hb}$ fraction at that time consisted of $99 \%$ for the $\mathrm{I}_{\alpha_{2}}{ }^{\mathrm{B}} \beta_{2} \mathrm{C}$ component. The ratio between the two $\beta{ }^{\mathrm{C}}$ components $\left({ }^{\mathrm{I}} \alpha_{2} \mathrm{~B} \beta_{2} \mathrm{C}: 58 \%\right.$ and $\mathrm{II}_{\alpha_{2}} \beta_{2} \mathrm{C}: 39.5 \%$ ) corresponded rather well with the ratios of the $\beta^{\mathrm{A}}$ components observed in the adult BB goat [18].

hemoglobins started rising on the 4th day. The level was at its maximum about 14 days later, when approximately $20 \%$ of the $\beta$ A chain was replaced by the $\beta^{\mathrm{C}}$ chain. This increased level of $\beta \mathrm{C}$ containing hemoglobins was maintained for about 20 days and was followed by a slow decrease to normal levels. No reticulocytosis was observed. 


\section{Discussion}

The most striking features of these investigations were the large production of the $\beta \mathrm{C}$ chain in the normal, nonanemic newborn kids after birth, the apparent relation between a humoral plasma factor and the formation of this specific polypeptide chain and a greater sensitivity of newborn kids to the stimulus initiating the $\beta \mathrm{C}$ production when compared with newborn lambs. The $\beta \mathrm{C}$ chain almost totally replaced the $\gamma$ chain in newborn kids, while in the newborn lambs, only up to $10 \%$ of the $\beta$ chains replacing the $\gamma$ chains were of the $\beta^{\mathrm{C}}$ type.

The changes noted in red cell morphology of these fast growing animals during the first three months of life confirm observations made by BARTELs et al. $[2,40]$. These investigators observed also changes in the affinity for molecular oxygen of blood samples collected at different time intervals after birth and reported that, in the weeks following birth, oxygen dissociation curves move to the right, even beyond the average adult blood samples. This phenomenon was most striking in the kid and was observed to a lesser extent in infants. A comparison of the oxygen affinity data of the newborn kid, shown in figure 1 of their 1961 publication [40], with our findings on the $\beta^{\mathrm{C}}$ production in this animal during the first three months of life (figs. 3 and 4) delineates close correlation between these two observations. The gradual decrease in oxygen affinity (indicated by a steady increase in the $\mathrm{P}_{50}$ values from $26.5 \mathrm{~mm} \mathrm{Hg}$ on day 5 to approximately $36 \mathrm{~mm} \mathrm{Hg}$ on day 42), followed by a slow decrease to values approaching those observed in adult goats, corresponds remarkably to the disappearance of $\mathrm{Hb}-\mathrm{F}$ (complete after 40 days), the increase in $\beta^{\mathrm{C}}$ containing hemoglobins (maximal between 40 and 50 days after birth) and the gradual replacement of $\beta^{\mathrm{C}}$ containing hemoglobins by $\beta^{\mathrm{A}}$ containing hemoglobins. This correlation becomes even more apparent from our recent observation [28] that the oxygen affinity of blood from severely anemic goats, with $100 \% \beta \mathrm{C}$ containing hemoglobin types, is significantly decreased, while the Bohr effect is moderately increased. It appears that the large production of $\beta \mathrm{C}$ containing hemoglobin types in this animal species during the first 3 months after birth is directly responsible for the observed change in functional properties. This phenomenon will influence oxygen transport because the presence of $\beta \mathrm{C}$ containing hemoglobin types in these nonanemic animals will increase the ability of the blood to release oxygen to tissues.

One wonders if a similar phenomenon exists in humans. Recent studies by ScHroeder et al. [42] have offered evidence for the structural heterogeneity of human fetal hemoglobin. It seems that at least two (and possibly more) types of $\gamma$ polypeptide chains are

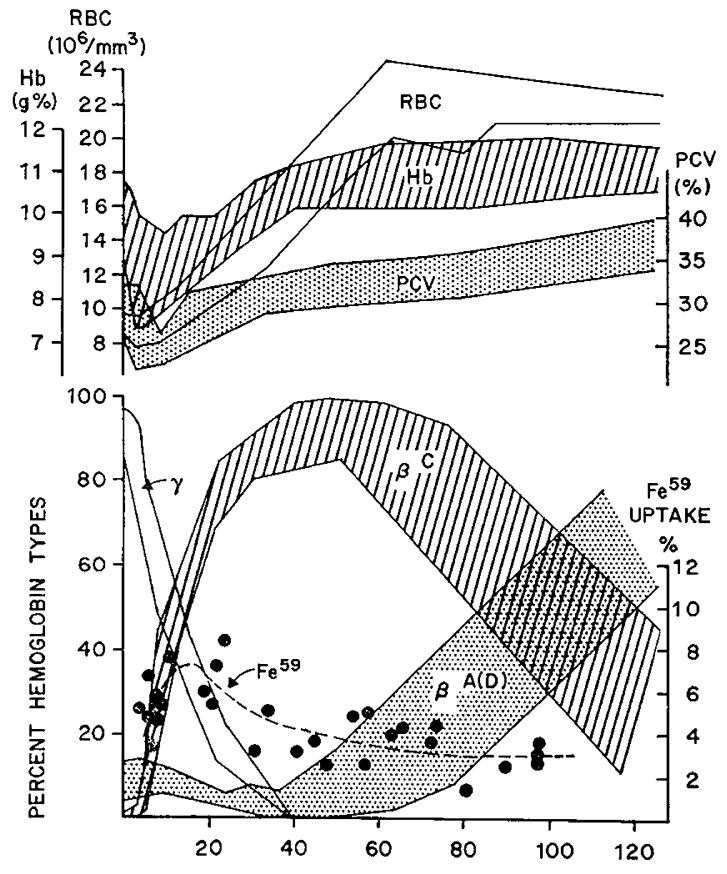

Fig.4. A comparison of the hematological data and the quantities of the $\gamma, \beta^{\mathrm{A}}$ (and $\beta^{\mathrm{D}}$ ) and $\beta^{\mathrm{C}}$ chains observed in 5 newborn kids over a period of 120 days, with the activities of the erythropoietic stimulating factor (expressed in $\%$ of injected $\mathrm{Fe}^{59}$ incorporated during 48 hours by the erythrocytes of polycythemic assay mice due to $1 \mathrm{ml}$ of goat serum) determined in the sera of 7 additional newborn kids over a period of 100 days.

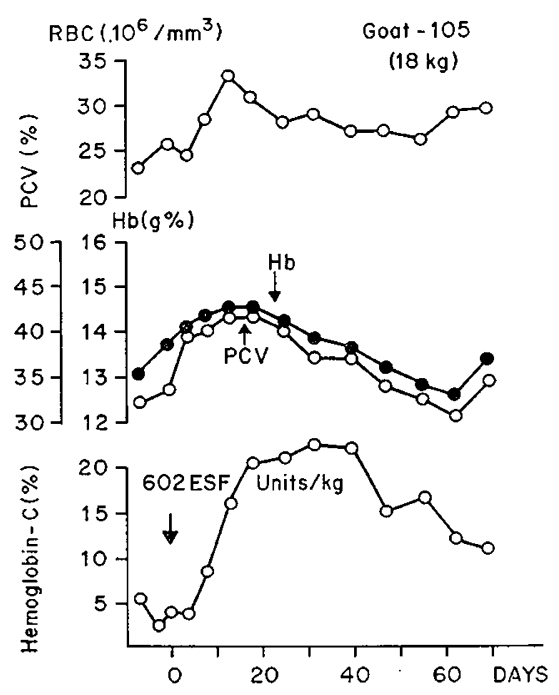

Fig.5. The effect of erythropoietic stimulating factor on the production of $\beta^{\mathrm{C}}$ containing hemoglobin in goat 105 (AB). 
synthesized in the normal human fetus; these $\gamma$ chains differ at a minimum in one residue, namely, residue 136, which is occupied either by a glycyl or an alanyl residue. Structural analyses of $\gamma$ chain abnormal varients have left little doubt as to the genetic basis of this heterogeneity of human fetal hemoglobin. No information is presently available of possible changes in the quantitative relation of these fetal hemoglobin types during the first few months of life, nor of possible functional differences between these fetal hemoglobins. Although the relative increase after birth of one specific fetal hemoglobin, that which also exhibits a decreased affinity for molecular oxygen, cannot be excluded, a second possible explanation for the observed changes in the oxygen equilibria appears from the recent studies by Benesch and Benesch $[4,5]$. Their investigations have shown that 2,3 diphosphoglycerate (2,3 DPG), which is present in a relatively large amount in the adult human red cells, acts as a regulator of the hemoglobin oxygen affinity. The 2,3 DPG greatly facilitates the release of oxygen from hemoglobin because of the greater affinity of the compound for the deoxygenated form than for the oxygenated form. The 2,3 DPG content of the human fetal red cells may be lower than that of the adult erythrocytes [41]. It seems that an increase in the formation of 2,3 DPG after birth is a possible regulator in decreasing the oxygen affinity of the red blood cells during this period. The 2,3 DPG is virtually absent in the erythrocytes of sheep and goats [39], and the regulation of the oxygen equilibria of the blood of newborn kids and lambs after birth may demand a mechanism different from that proposed for the human infant, namely, the synthesis of specific $\beta \mathrm{C}$ chain-containing hemoglobin types with altered functional properties.

The observation that a humoral factor can initiate an increase in production of $\beta^{\mathrm{C}}$ chains was first reported by Moore et al. [37] and has been confirmed by others $[9,17]$. Our recent findings, namely the elevated ESF activities in the plasma of newborn kids 10 to 30 days after birth and the increased formation of $\beta^{\mathrm{C}}$ chains in young lambs and kids after administration of ESF material isolated from human urine, also support this possibility. The nature of the humoral factor remains obscure; our observations suggest that the stimulation of the $\beta \mathrm{C}$ production in sheep and goats is a property of an unidentified protein, which could possibly be that designated as erythropoietin. The exact nature of the response to an increased concentration of the factor (either by an increased endogenous production or by administration of exogenous material) is also unknown. The physiological change in the newborn kids apparently signals an increased production of ESF factor (or factors) over a relatively long period. This increased ESF activity is accompanied by a mild reti- culocytosis (maximal around day 20) and by the appearance of $\beta^{\mathrm{C}}$ chain-containing hemoglobins (maximal around days 40 to 50 ). These observations could indicate that at least two mechanisms are involved which are influenced by the same factor or perhaps by two separate factors. One concerns the acute stimulus of the bone marrow to produce red blood cells as is manifested by the reticulocyte response, while the second concerns the increased production of the $\beta^{\mathrm{C}}$ polypeptide chain, a qualitative rather than a quantitative response.

A series of events similar to those observed in the newborn kid is likely to occur in the newborn lamb. In comparing these phenomena, one wonders why the response to an apparent mild increase in activity of endogenous ESF results in a considerably larger production of the $\beta^{\mathrm{C}}$ chain in the newborn kid than in the newborn lamb. It is impossible to state positively that administration of exogenous ESF in lambs and kids results in a similar response difference; the data shown in figures 2 and 5 are too different for a quantitative evaluation of the results. In this context, sheep and goats, when subjected to a similar bleeding technique, are equally good producers of ESF. The response of these adult animals to this identical stress, however, is quantitatively different in that the sensitivity in goats to the stimulus for $\beta \mathrm{C}$ synthesis is considerably greater than that in sheep $[1,24,37,43]$. The explanation for these differences may be found in the possible presence of a negative feedback inhibitor [13]. The possibility that an activator-inhibitor complex is produced and assumes an important role in the regulation of erythropoiesis [36], has been recently supported by the isolation of a protein fraction from the urine of four anemic patients with a relatively potent ESF inhibitory activity [34]. This protein may be the same as the ESF inhibitor observed by others [16, 30, 31]. Assuming that an activation-inhibition mechanism does operate in both animal species, it appears that the greater sensitivity for $\beta \mathrm{C}$ production in the goat could be due to a relative deficit in the formation of the feedback inhibitor in this animal. The absence of a large production of $\beta \mathrm{C}$ chain-containing hemoglobin in sheep during the postnatal period may be explained, in part, by the difference observed between the oxygen affinities of sheep hemoglobin $\mathrm{C}$, which is similar to that of sheep hemoglobin A, and of goat hemoglobin C, which is considerably less than that of goat hemoglobin $\mathrm{A}$ at physiological $\mathrm{pH}$ values $[28,43]$. These observations would imply that the production of hemoglobin $\mathrm{C}$ during the newborn period would be of no advantage to the newborn lamb, in contrast to the newborn kid.

An explanation of the nature of the $\beta^{\mathrm{A}}$ to $\beta^{\mathrm{C}}$ switchover mechanism as a response to an increased production of an ESF plasma factor is highly speculative. It appears that the mechanism could involve a direct 
interaction between the factor and either the $\mathrm{Hb}_{\beta} \mathrm{C}$ structural gene (inducing $\beta^{\mathrm{C}}$ chain production) or the $\mathrm{Hb}_{\beta} \mathrm{A}$ structural gene (inhibiting $\beta^{\mathrm{A}}$ chain production with an increase in $\beta^{\mathrm{C}}$ chain production as a secondary response), or both. An alternate explanation can be based on an interference of the ESF factor alone or as part of an activator-inhibitor complex with the operator-regulator mechanism involved in controlling the rates of synthesis of the $\mathrm{Hb}_{\beta} \mathrm{A}$ and $\mathrm{Hb}_{\beta} \mathrm{c}$ structural genes, if a similar mechanism does exist in mammals as was observed in bacteria [29].

\section{References and Notes}

1. Adams, H. R.; Boyd, E. M.; Wilson, J. B. ; Miller, A. and Husman, T.H.J.: The structure of goat hemoglobins. III. Hemoglobin D, a $\beta$ chain variant with one apparent amino acid substitution (21 Asp $\rightarrow$ His). Arch. Biochem. 127: 398 (1968).

2. Bartels, H.; Hilpert, P. und Riegel, K.: Die $\mathrm{O}_{2}$-Transportfunktion des Blutes während der ersten Lebensmonate von Mensch, Ziege und Schaf. Pflügers Arch.ges. Physiol. 271: 169 (1960).

3. Beale, D.; Lehmann, H.; Drury, A. and Tucker, E. M. : Haemoglobins of sheep. Nature, Lond. 209: 1099 (1966).

4. Benesch, R. and Benesch, R.E.: The effect of organic phosphates from the human erythrocyte on the allosteric properties of hemoglobin. Biochem. Biophys. Res. Commun. 26: 162 (1967).

5. Benesch, R.; Benesch, R.E. and Yu, C. I.: Reciprocal binding of oxygen and diphosphoglycerate by human hemoglobin. Proc. nat. Acad. Sci. 59: 526 (1968).

6. Blunt, M.H. and Evans, J.V.: Changes in the concentration of potassium in the erythrocytes and in haemoglobin type in Merino sheep under a severe anaemic stress. Nature, Lond. 200: 1215 (1963).

7. Boyer, S. H.; Hathaway, P.; Pascasio, F.; OrTon, G.; Bordley, J. and Naugrton, M. A.: Hemoglobins in sheep: Multiple differences in amino acid sequences of three $\beta$ chains and possible origins. Science 153: 1539 (1966).

8. Boyer, S. H.; Hathaway, P.; Pascasio, F.; BordLey, J.; Orton, C. and Naughton, M. A.: Differences in the amino acid sequences of tryptic peptides from three sheep hemoglobin $\beta$ chains. J. biol. Chem. 242: 2211 (1967).

9. Boyer, S.H.: Personal communication.

10. Braend, M.; Efremov, G. and Helle, O.: Abnormal haemoglobin of sheep. Nature, Lond. 204: 700 (1964).

11. Braend, M. and Efremov, G.: Haemoglobin $N$ of sheep. Nature, Lond. 205: 186 (1965).
12. Breathnach, G.S.: Foetal and neonatal haemoglobins in sheep and goats. Quart.J.Physiol. 49: 277 (1964).

13. Brecher, G. and Stohlman, F., Jr.: Humoral factors in erythropoiesis. Progr. Hemat., vol. 2, p. 110 (Grune and Stratton, New York 1959).

14. Dozy, A.M.; Kleinhauer, E.F. and Huisman, T.H.J.: Studies on the heterogeneity of hemoglobin. XIII. Chromatography of various human and animal hemoglobin types on DEAE-Sephadex. J. Chromatog. 32: 723 (1968).

15. DruRy, A. and Tucker, E. M.: The haemoglobin changes in the newborn lamb. J. Physiol. 162: 16P (1962).

16. Fisher, J.W.; Hatch, F.E.; Rott, B.L.; Allen, R.C. and Kelley, B.J.: Erythropoietin inhibitor in kidney extracts and plasma from anemic uremic human subjects. Blood 31: 440 (1968).

17. Gabuzda, T.G.; Schuman, M.A.; Silver, R.K. and Lewis, H.B.: Induction of changed hemoglobin phenotype in homozygous A sheep (Abstract). Blood 30: 865 (1967).

18. Garrick, M.D. and Huisman, T.H.J.: Gene duplication for the $\alpha$ chain of goat hemoglobin: Evidence for a homozygous mutant. Biochim. biophys. Acta 168: 585 (1968).

19. Hansen, P.: The precipitation of erythropoietin from urine by means of tannic acid. Use in analysis and production of ery thropoietin-rich preparations. Scand.J. clin. Lab. Invest. 15: 631 (1963).

20. HARRIS, H. and WARREN, F.L.: Occurrence of electrophoretically distinct haemoglobins in ruminants. Biochem.J. 60: XXIX (1955).

21. Huisman, T.H.J.: Normal and abnormal human hemoglobins. Advanc.clin. Chem., vol.6, p.231 (Academic Press, New York 1963).

22. Huisman, T.H.; Visser, H. K. and VAN der Helm, H.J.: Evidence of the second foetal haemoglobin in the newborn goat. Nature, Lond. 180: 758 (1957).

23. Hursman, T.H.J. and Dozy, A. M.: Studies on the heterogeneity of hemoglobins. IX. The use of tris (hydroxymethyl)aminomethane-HCl buffers in the anion-exchange chromatography of hemoglobins. J. Chromatog. 19: 160 (1965).

24. Huisman, T.H.J.; Adams, H. R.; Dimmock, M.O.; EDWARDS, W.C. and WrLson, J.B.: The structure of goat hemoglobins. I. Structural studies of the $\beta$ chains of the hemoglobins of normal and anemic goats. J. biol. Chem. 242: 2534 (1967).

25. Hursman, T.H.J.; Wrison, J.B. and Adams, H.R.: The heterogeneity of goat hemoglobin: Evidence for the existence of two nonallelic and one allelic $\alpha$ chain structural genes. Arch.Biochem. 121:528 (1967). 
26. Huisman, T.H.J.; Brandt, G. and Wilson, J. B. The structure of goat hemoglobins. II. Structural studies of the $\alpha$ chains of the hemoglobins A and B. J. biol. Chem. 243: 3675 (1968).

27. Huisman, T.H.J.; Dozy, A.M.; Wilson, J.B.; Efremov, G.D. and VasKov, B.: Sheep hemoglobin $\mathrm{D}$, an $\alpha$ chain variant with one apparent amino acid substitution ( $\alpha 15$ Gly $\rightarrow$ Asp). Biochim. biophys. Acta 160: 467 (1968).

28. Huisman, T.H.J. and Kitchens, J.: Oxygen equilibria studies of the hemoglobins from normal and anemic sheep and goats. Amer.J.Physiol. 215: 140 (1968).

29. JACOB, F. and MoNOD, J.: On the regulation of gene activity. Cold Spr.Harb.Symp.quant. Biol. 26: 193 (1961).

30. JePson, J.H. and Lowenstern, L.: Inhibition of erythropoiesis by a factor present in the plasma of patients with erythroblastopenia. Blood 27: 425 (1966).

31. Krzymowska, H.: The effect of plasma extracts from rats injected with hemolysates on erythropoiesis inhibition in mice. Pol. Arch. weteryn. 10: 63 (1966).

32. Lewis, J.P.; Alford, D.A.; Rathjen, J.H., Jr. and LANGE, R.D.: Preparation of human urine concentrate for erythropoietin studies. J.Lab.clin. Med. 66: 987 (1965).

33. Lewis, J.P.; Alford, D.A.; Wright, C.-S.; G.ARDNeR, E., Jr.; RathJen, J.H., Jr. and Moores, R.R.: Fractionation of erythropoietin by selective membrane permeability. Acta haemat., Basel 38: 372 (1967).

34. Lewis, J. P.; Neal, W.A.; Moores, R.R.; Alford, D.A.; Gardner, E., Jr.; Smith, L.L.; Wright, C.S. and Scharnitzky, W. A.: A protein inhibitor of erythropoietin. Abstract. J. Lab. clin. Med. 72: 989 (1968).

35. Lewis, J.P.: Unpublished observations.

36. Linman, J.W.; Long, M.J.; Korst, D.R. and Bethell, F.H.: Studies on the stimulation of hemopoiesis by butyl alcohol. J. Lab. clin. Med. 54: 335 (1959).

37. Moore, S.L.; Godley, W.G.; van Vliet, G.; Lewis, J.P.; Boyd, E. and Hursman, T.H.J.: The production of hemoglobin $\mathrm{C}$ in sheep carrying the gene for hemoglobin A: Hematologic aspects. Blood 28: 314 (1966).

38. Pavlovic-Kentera, V.; Hall, D.P.; Bragassa, C. and LANGE, R.D.: Unilateral renal hypoxia and production of erythropoietin. J.Lab.clin. Med. 65: 577 (1965).

39. RAPOPORT, S. and GUEST, G. M.: Distribution of acid-soluble phosphorus in the blood cells of various vertebrates. J. biol. Chem. 138: 269 (1941).
40. Riegel, K.; Hilpert, P. und Bartels, H.: Vergleichende Untersuchungen der Erythrocytenmorphologie, des fetalen Hämoglobins und der Sauerstoffaffinität des Blutes von Säuglingen, Zicklein und Lämmern. Acta haemat., Basel 25: 164 (1961).

41. Rohdewald, M. und Weber, M.: Über den papierchromatographisch ermittelten Gehalt von Phosphor-Verbindungen in der säurelöslichen Fraction des menschlichen Blutes. II. Untersuchungen am Blut von Kindern. Hoppe-Seylers Z. Physiol. 311: 239 (1958).

42. Schroeder, W.A.; Huisman, T.H.J.; Shelton, J.R.; Shelton, J.B.; Kleihauer, E.F.: Dozy, A.M. and Robberson, B.: Evidence for multiple structural genes for the $\gamma$ chain of human fetal hemoglobin. Proc.nat. Acad.Sci. 60: 357 (1968).

43. van Vliet, G. and Hutsman, T.H.J.: Changes in the haemoglobin types of sheep as a response to anaemia. Biochem.J. 93: 401 (1964).

44. Vaskov, B. and EFremov, G.: Fourth haemoglobin type in sheep. Nature, Lond. 216: 593 (1967).

45. VisSer, H. K. A.; Hursman, T. H.J. and Woldring, M. G.: The postnatal synthesis of fetal hemoglobin: Some studies in newborn goats using radioactive $\mathrm{Fe}^{59}$ and glycine-2-C ${ }^{14}$. Blood 12: 1004 (1957).

46. Wilson, J.B.; Edwards, W. C.; MaDaniel, M.; Dobbs, M. M. and Hursman, T.H.J.: The structure of sheep hemoglobins. II. The amino acid compositions of the tryptic peptides of the non $\alpha$ chains of hemoglobins A, B, C and F. Arch. Biochem. 115: 385 (1966).

47. Wilson, J. B.; Brandr, G. and Huisman, T.H.J.: The structure of sheep hemoglobins. III. Structural studies of the $\alpha$ chain of hemoglobin A. J.biol. Chem. 243: 3687 (1968).

48. Wintrobe, M.M.: Clinical hematology (Lea and Febiger, Philadelphia 1962).

49. Supported by USPHS grants HE-05168 (THJH) and HE-10591 (JPL).

50. On study leave from the Department of Agricultural Biology, Faculty of Rural Science, University of New England, Armidale, N.S.W., Australia.

51. This paper contains material that is to be utilized in a dissertation as partial fulfillment of the Ph.D. requirements for H. R. ADAms.

52. Standard B was distributed by The Medical Research Council, National Institute for Medical Research, London (England).

53. Animals were made available by Goduey, W.L., Ph.D., and Moore, S., D.V.M., Clemson University, Clemson, S.C. (USA).

54. Requests for reprints should be addressed to: Titus H.J.Hursman, Ph.D.D.Sc., Department of Biochemistry, Division of Protein Chemistry, Medical College of Georgia, Augusta, Ga. 30902 (USA). 